\title{
On the Voronovskaja-type formula for the Bleimann, Butzer and Hahn bivariate operators
}

\section{DAN BĂRBOSU and DAN MICLĂUŞ}

\section{ABSTRACT.}

In this paper we present two new alternative ways for the proof of Voronovskaja-type formula of the Bleimann, Butzer and Hahn bivariate operators, using the close connection between the recalled operators and Bernstein bivariate operators, respectively Stancu bivariate operators.

\section{REFERENCES}

[1] Abel, U., On the asymptotic approximation with operators of Bleimann, Butzer and Hahn, Indag. Math., 7 (1996), No. 1, 1-9

[2] Abel, U., On the asymptotic approximation with bivariate operators of Bleimann, Butzer and Hahn, J. Approx. Theory, 97 (1999), No. 3, 181-198

[3] Abel, U. and Ivan, M., Some identities for the operator of Bleimann, Butzer and Hahn involving divided differences, Calcolo, 36 (1999), 143-160

[4] Abel, U. and Ivan, M., On Bleimann, Butzer and Hahn operators on exponential functions, Bull. Austral. Math. Soc., 75 (2007), 409-415

[5] Abel, U. and Ivan, M., An answer to Hermann's conjecture on Bleimann-Butzer-Hahn operators, J. Approx. Theory, 160 (2009), 304-310

[6] Adell, J. A., Badia, F. G. and De la Cal, J., On the iterates of some Bernstein-type operators, J. Math. Anal. Appl., 209 (1997), 529-541

[7] Agratini, O., Approximation properties of a generalization of Bleimann, Butzer and Hahn operators, Math. Pannonica, 9 (1998), No. 2, 165-171

[8] Altin, A., Dogru, O. and Özarslan, M. A., Korovkin type approximation properties of bivariate Bleimann, Butzer and Hahn operators, Proceed. of 8-th WSEAS Int. Conf. on Appl. Math., Tenerife, Spain, December 16-18, 2005, 234-238

[9] Bărbosu, D., Some applications of Shisha-Mond theorem, Creat. Math. Inform., 23 (2014), No. 2, 141-146

[10] Bărbosu, D., The Schurer-Stancu approximation formula revisited, Creat. Math. Inform., 22 (2013), No. 1, 15-18

[11] Bărbosu, D., Two dimensional devided differences revisited, Creat. Math. Inform. 17 (2008), No. 1, 1-7

[12] Bărbosu, D., Acu, A. M. and Sofonea, F. D., The Voronovskaja-type formula for the Bleimann, Butzer and Hahn operators, Creat. Math. Inform., 23 (2014), No. 2, 137-140

[13] Bărbosu, D. and Pop, O. T., Bivariate uniform approximation via bivariate Lagrange interpolation polynomials, Creat. Math. Inform., 23 (2014), No. 1, 7-13

[14] Bărbosu, D. and Pop, O. T., A cubature formula of Schurer-Stancu type, Creat. Math. Inform., 18 (2009), No. 2, 103-109

[15] Bernstein, S. N., Démonstration du théorème de Weierstrass fondée sur le calcul de probabilités, Commun. Soc. Math. Kharkow, (2), 13 (1912-1913), 1-2

[16] Bleimann, G., Butzer, P. L. and Hahn, L., A Bernstein-type operator approximating continuous functions on the semi-axis, Nederl. Akad. Wetensch. Indag. Math., 42 (1980), 255-262

[17] Braica, P. I., Pop, O. T. and Bărbosu, D., Schurer operators of King type, Creat. Math. Inform., 22 (2013), No. 2, $161-171$

Received: 09.11.2015; In revised form: 03.04.2016; Accepted: 04.05.2016

2010 Mathematics Subject Classification. 41A10, 41A36, 41A63.

Key words and phrases. Linear operators, bivariate operators, Bernstein operators, Bleimann, Butzer and Hahn operators, Stancu operators, Voronovskaja-type formula.

Corresponding author: Dan Miclăuş; danmiclausrz@yahoo.com 
[18] Hermann, T., On the operator of Bleimann, Butzer and Hahn, in Proceedings Conference on Approximation theory, Kecskemét Hungary 1990, (Szabados, J. et al., Eds.), North-Holland Publishing Company, Amsterdam, Colloq. Math. Soc. János Bolyai, 58 (1991), 355-360

[19] Ivan, M., A note on the Bleimann, Butzer and Hahn operator, Automat. Comput. Appl. Math., 6 (1997), 11-15

[20] Ivan, M., Elements of Interpolation Theory, Mediamira Science Publisher, Cluj-Napoca 2004

[21] Jayasri, C. and Sitaraman, Y., Direct and inverse theorems for certain Bernstein-type operators, Indian J. Pure Appl. Math., 16 (1985), No. 12, 1495-1511

[22] Jayasri, C. and Sitaraman, Y., On a Bernstein-type operator of Bleimann, Butzer and Hahn, J. Comput. Appl. Math., 47 (1993), No. 2, 267-272

[23] Mercer, A. McD., A Bernstein-type operator approximating continuous functions on the half-line, Bull. Calcutta Math. Soc., 81 (1989), 133-137

[24] Miclăuş, D., On the GBS Bernstein-Stancu's type operators, Creat. Math. Inform., 22 (2013), No. 1, 73-80

[25] Miclăuş, D. and Braica, P. I., The generalization of some results for Bernstein and Stancu operators, Creat. Math. Inform., 20 (2011), No. 2, 147-156

[26] Miclăuş, D. and Pop, O. T., The Voronovskaja theorem for some linear positive operators defined by infinite sum, Creat. Math. Inform., 20 (2011), No. 1, 55-61

[27] Pişcoran, L. I., Pop, O. T. and Bărbosu, D., Bézier type surfaces, Appl. Math. Inf. Sci., 7 (2013), No. 2, 483-489

[28] Pop, O. T., The generalization of Voronovskaja's theorem for a class of bivariate operators, Stud. Univ. Babeş-Bolyai Math., 53 (2008), No. 2, 85-108

[29] Pop, O. T., Bărbosu, D. and Pişcoran, L. I., Bézier type curves generated by some class of positive linear operators, Creat. Math. Inform., 19 (2010), No. 2, 191-198

[30] Pop, O. T. and Bărbosu, D., The Voronovskaja theorem for some Stancu-type operators, Creat. Math. Inform., 18 (2009), No. 1, 57-64

[31] Stancu, D. D., The remainder of certain approximation formulas in two variables, J. Soc. Indust. Appl. Math., Ser. B, Numer. Anal., 1 (1964), 137-163

[32] Stancu, D. D., On a generalization of the Bernstein polynomials (in Romanian), Stud. Univ. Babeş-Bolyai, Ser. Math.-Phys., 14 (1969), 31-45

[33] Totik, V., Uniform approximation by Bernstein-type operators, Nederl. Akad. Wetensch. Indag. Math., 46 (1984), 87-93

\author{
Department of MATHEMATICS ANd COMPUter SCIENCE \\ NORTh University CENTER AT BAIA MARE \\ TECHNICAL UNIVERSITY OF ClUJ-NAPOCA \\ VICTORIEI 76, 430122 BAIA MARE ROMANIA \\ E-mail address: barbosudan@yahoo.com \\ E-mail address: danmiclausrzeyahoo.com
}

